\title{
Mempertimbangkan Budaya Lokal untuk Ibadah Komunal Kaum Muda yang Utuh
}

\section{Cristin Logo}

D alam suatu ibadah minggu remaja, seorang pengkhotbah bertanya dengan wajah yang antusias dan tersenyum ramah kepada para remaja yang hadir, "Adik-adik, apa yang membuat kalian datang beribadah setiap minggu?" Sambil menunggu jawaban mereka, pengkhotbah tersebut berjalan perlahan mendekati baris depan. Terlihat beberapa orang menyikut teman sebelahnya, sebagai dorongan untuk menjawab pertanyaan itu. Terdengar juga suara bisikan mereka, yang menandakan sedang terjadinya sebuah diskusi. Ada juga yang mencoba untuk memikirkannya sendiri dengan kening yang berkerut kecil. Akan tetapi, tidak ada satupun yang berani untuk menjawabnya. Pengkhotbah tersebut kembali mengulang pertanyaannya dengan jarak yang lebih dekat dengan mereka yang duduk di baris depan, sambil menunjuk beberapa dari mereka untuk menjawab. Beberapa jawaban pun terucapkan kepada mereka yang ditunjuk; "Memuji Tuhan!", "Menyembah Tuhan!”, "Mendengarkan firman Tuhan!", "sama dengan yang tadi!", dan lainnya, yang juga senada dengan jawaban-jawaban tersebut.

Dengan wajah yang cukup puas, peng- khotbah tersebut perlahan membalikkan badannya untuk kembali ke dekat mimbar. Sembari itu terjadi, dengan suara yang cukup lantang dan berani, seorang remaja mencoba untuk menjawab, "karena rindu dengan Tuhan." Kemudian, pengkhotbah itu dengan cepat membalikkan badannya kembali, dan terlihat lebih 'semringah' dari yang tadi. Suasana ruang ibadah juga menjadi sedikit lebih riuh setelah jawaban itu dilontarkan. Senyum-senyum kecil diarahkan teman-temannya kepada remaja yang menjawab itu. Kemudian, sambil mendekati remaja tersebut, pengkhotbah itu melontarkan pertanyaan lagi, "rindu yang seperti apa yang kamu rasakan?", lalu tanpa berpikir lama, remaja itu menjawab, "seperti rusa yang haus." Sontak jawaban itu meledakkan tawa sang pengkhotbah, begitu juga dengan jemaat yang lain, dan tepukan tangan yang ramai pun diberikan kepada remaja tersebut. "Hahahahahaha, bener nih? Hebat kamu, memang harus begitu... hahahahaha," begitu kata sang pengkhotbah.

Entah alasan apa yang membuat ledakan tertawa itu terjadi, apakah itu wujud ledekan, kesalutan, atau ketidakpercayaan akan kesungguhan remaja tersebut. Entah alasan apa juga yang membuat remaja itu 


\section{Ibadah komunal yang utuh itu sendiri adalah ketika Cerita Allah yang disampaikan, dapat dialami secara utuh oleh cerita manusia, baik dengan keberadaan dirinya sebagai individu maupun juga komunitas, yang dengan keutuhan itu, mereka berparti- sipasi secara aktif di dalam ibadah, juga dalam keseharian hidup, sampai Cerita Allah itu mentransformasi keutuhan ce- rita manusia itu sendiri.}

menjawab pertanyaan tersebut dengan jawaban nya yang sedemikian rupa. Apakah dia bersungguh-sungguh, atau hanya sekadar teringat dengan sepenggal lirik lagu, dan kemudian diucapkannya dengan lantang. Apapun itu, bukankah mereka yang datang beribadah memang seharusnya datang dengan hasrat yang rindu kepada Allah dan ingin dipenuhi oleh Allah sendiri? Bukan kah dengan hasrat itulah seseorang memuji, menyembah, mengakui dosa, mendengarkan khotbah, mengikrarkan pengakuan iman, memberikan persembahan, dan lainnya? Bukankah dengan hasrat itu juga yang membuat seseorang, dengan keutuhan hidupnya, menanti-nantikan sebuah pengalaman ibadah yang utuh itu, sampai semuanya itu dipenuhi oleh Allah, dan keutuhan hidup nya diubahkan? Bukankah semua itu yang seharusnya terjadi dalam ibadah komunal?

Di dalam ibadah komunal, Allah menyatakan cerita-Nya, yang kemudian bertemu dan berdialog dengan cerita manusia. Sehingga, ibadah komunal itu sendiri dapat dikatakan sebagai wahana pertemuan Cerita Allah dan cerita manusia, seperti yang dikatakan Anderson dan Foley bah wa ibadah memiliki potensi untuk memfasilitasi pertemuan Ilahi dan manusia, di mana cerita manusia menjadi terikat dengan Allah. ${ }^{1}$ Dalam ibadah komunal, Cerita Allah itu disampaikan melalui berbagai ritual dan story telling. Bahkan ibadah dapat dikatakan sebagai ritual dari story telling Allah, yang terus menerus diulang di setiap minggunya, melalui bentuk yang lebih eksplisit (seperti menyanyi, berdoa, pengakuan iman, persembahan, dan lain nya). Ibadah komunal yang utuh itu sendiri adalah ketika Cerita Allah yang disampaikan, dapat dialami secara utuh oleh cerita manusia, baik dengan keberadaan dirinya sebagai individu maupun juga komunitas, yang dengan keutuhan itu, mereka berpartisipasi secara aktif di dalam ibadah, juga dalam keseharian hidup, sam pai Cerita Allah itu mentransformasi keutuhan cerita manusia itu sendiri. Berikut ini penulis mema-

1. Herbert Anderson dan Edward Foley, Mighty Stories, Dangerous Rituals: Weaving Together the Human and the Divine (San Francisco, California: Jossey-Bass, 1998), 42. Pernyataan ini dilontarkan Anderson dan Foley dengan suatu pengakuan bahwa dalam keberadaan yang potensial tersebut, ibadah sering kali tidak cukup memediasi pertemuan ini, bahkan sering kali gagal melakukannya, dan justru menjadi suatu hal yang membosankan dan tidak relevan. Sedangkan, ibadah sendiri merupakan medium yang signifikan. 
parkan secara singkat mengenai apa yang dimaksud dengan ibadah komunal yang utuh itu.

\section{Ibadah Komunal yang Utuh}

Pertama, ibadah komunal yang utuh adalah ibadah yang di dalamnya terdiri dari individu dan komunitas yang utuh. Jemaat tidak hanya datang dengan kesadaran akan keutuhan dirinya sebagai individu, namun juga sebagai keutuhan dirinya di dalam komunitas. Ini terkait dengan natur dari penyataan Cerita Allah itu sendiri, di mana Allah menyatakan diri-Nya sebagai Allah yang personal, spiritual, imanen, dan transenden, yang berelasi secara dekat dan personal dengan individu-individu. ${ }^{2}$ Bukan hanya kepada individu saja, namun Allah juga menyatakan dirinya kepada komunitas, dan penyataan tersebut dialami secara objektif, di mana keobjektivitasan dalam ibadah komunal ini menunjukkan bahwa kekudusan, transendensi, dan kemutlakan Allah adalah kebenaran yang objektif. ${ }^{3}$

Oleh karena Allah menyatakan diriNya secara utuh kepada individu dan komunitas, maka seharus nya, individu dan komunitas tersebut juga datang beribadah dengan personalitas dan komunalitas yang utuh. Pengetahuan, emosi, dan kehendak (pikiran, jiwa, roh, dan tubuh) dibawa untuk ikut terlibat di dalam ibadah. ${ }^{4}$ Allah sendiri memang menghendaki keutuhan manusia dalam berelasi dengan-Nya, se- hingga Ia memerintahkan manusia untuk mengasihi-Nya dengan keutuhan hidup (Mat. 22:37). Unsur komunalitas yang utuh dalam ibadah itu sendiri terkait dengan perintah Allah kepada umat-Nya untuk beribadah sebagai orang-orang yang telah diselamatkan dan dipersatukan dalam kesatuan tubuh-Nya. Dengan demikian, di dalam ibadah komunal, tercipta relasi antara Allah, individu secara personal, dan juga dengan kesatuan komunitas tubuh Kristus.

Kedua, ibadah komunal yang utuh adalah ibadah yang keutuhan individu dan komunitasnya juga berpartisipasi dan berelasi secara utuh dan aktif. Jemaat bukan hanya datang dengan kesadaran dan membawa keutuhan dirinya sebagai individu dan komunitas saja, namun dengan keutuhannya itu, mereka juga turut berpartisipasi. Tanpa partisipasi, relasi yang ada dalam komunalitas hanya menjadi relasi yang pasif. Don Saliers, sebagaimana yang dikutip Schmit, memberikan tiga level dalam partisipasi yang seharusnya terwujud dalam ibadah komunal. ${ }^{5}$ Level pertama, terkait dengan partisipasi yang dilakukan selama ibadah berlangsung, melalui keterlibatan dalam berdoa, menyanyi, memproklamasikan pengakuan iman, dan lainnya. Semuanya itu dilakukan dengan utuh, dan dengan suatu kesadaran, keaktifan, yang melibatkan hati, tindakan, perasaan, dan tenaga. Level kedua berbicara mengenai suatu

2. Franklin M. Segler dan Randall Bradley, Christian Worship: Its Theology and Practices (Nashville: B\&H, 2006 ), 50-51.

3. Segler dan Bradley, Christian Worship, 63.

4. Segler dan Bradley, Christian Worship, 61. Dalam hal ini, Segler dan Bradley sedang menjelaskan bagian psikologi yang terlibat dalam ibadah, yang didasarkan dengan penjelasan secara biblis.

5. Clayton J. Schmit, "Worship as a Locus for Transformation", dalam Worship that Changes Lives: Multidisciplinary and Congregational Perspective on Spiritual Transformation, ed. Alexis D. Abernethy (Grand Rapids: Baker Academic, 2008), 29-30. 
kesadaran yang lebih tinggi, bahwa jemaat juga datang beribadah sebagai kesatuan tubuh Kristus. Ini mengingatkan jemaat mengenai peran mer eka sebagai bagian dari tubuh Kristus, yang saling melengkapi, mendoakan, menegur, dan memohon pengampunan bersama, untuk kemuliaan Kristus sebagai kepala dari tubuh itu sendiri.

Level ketiga berbicara mengenai lapisan yang lebih tinggi lagi, di mana partisipasi itu terus berlanjut sampai kepada kehidupan keseharian yang dipimpin Allah. Level ini memberikan suatu pemahaman bahwa ibadah komunal bukan hanya dapat sedemikian rupa memberikan ruang bagi jemaat untuk berpartisipasi secara penuh di dalam ibadah. Namun juga berpartisipasi sebagai komunitas Kristus, yang terus berlanjut menembus dinding-dinding gereja. Indikator dari partisipasi ini adalah ketika jemaat secara aktif terlibat dalam mengimplementasikan pengajaran Allah ke dalam setiap lembaga kehidupan (keluarga, masyarakat, pekerjaan sehari-hari), sebagai dampak dari pertemuan di dalam ibadah. Di antaranya yaitu: hidup bersyukur, jujur, mengasihi tanpa syarat, menjaga kekudusan hidup, dan lainnya. Oleh sebab itu, dengan meninjau ketiga level partisipasi yang telah dijelaskan di atas, maka jemaat akan ikut terlibat dalam ibadah dengan berpartisipasi secara aktif dan utuh sebagai individu dan komunitas.
Partisipasi tersebut juga dihidupkan dalam keseharian, sampai terjadi suatu transformasi yang utuh.

Ketiga, ibadah komunal yang utuh adalah ibadah yang mewujudkan sebuah transformasi hidup yang utuh. Robert R. King dalam penelitiannya terhadap ibadah, lagu, dan transformasi spiritual di Afrika, memberikan penjelasan mengenai tiga dimensi yang terlibat dalam proses transformasi, yaitu afeksi, perilaku, dan kognisi. ${ }^{6}$ Ketiga dimensi ini sama-sama berpartisipasi, terhubung satu sama lain, dan membentuk suatu keyakinan dan tindakan yang diwujudkan, berdasarkan kebenaran yang diberikan di dalam ibadah. Ketiga dimensi ini juga adalah bagian dari keutuhan individu dan komunitas, yang bukan hanya berpartisipasi secara utuh di dalam ibadah, namun juga dalam hidup keseharian.

Partisipasi yang utuh dan aktif (dengan pikiran, tubuh, emosi, spirit), yang didasarkan pada hasrat untuk ditransformasi, menciptakan interaksi atau dialog yang memungkinkan terjadinya pembelajaran dan pembentukan hidup, sampai transformasi itu sendiri terjadi. Transformasi ini terjadi pada keutuhan individu juga komunitas, yang sama-sama berpartisipasi secara utuh di dalam ibadah, dan keseharian. Pembaharuan ini bukan berarti meniadakan peran Roh Kudus di dalamnya, namun juga bukan berarti meniadakan fokus dan modus transformatif

6. Robert R. King, "Under the Mango Tree: Worship, Song, and Spiritual Transformation in Africa”, dalam Worship that Changes Lives: Multidisciplinary and Congregational Perspective on Spiritual Transformation, ed. Alexis D. Abernethy (Grand Rapids: Baker Academic, 2008), 156-157.

\section{Youlfh | November 2015}


dalam pelaksanaan suatu ibadah. Tentu semuanya harus disertai dengan pengakuan akan keterlibatan Roh Kudus seutuhnya dalam memungkinkan terjadinya suatu transformasi yang utuh.

Dari pemaparan di atas, terlihat bahwa pertemuan antara Cerita Allah dan cerita manusia di dalam ibadah komunal merupakan suatu proses yang melibatkan keutuhan Allah dalam menyatakan diri-Nya, dan juga keutuhan jemaat dalam mengalami keutuhan Cerita Allah itu. Oleh sebab itu, ketika berbicara mengenai keutuhan yang melibatkan tindakan dan ucapan, emosi, pikiran, tenaga, hati, dan relasi dalam komunitas dalam ibadah itu sendiri, maka sesungguhnya di sinilah budaya itu terlibat.

\section{Memahami Budaya Lokal}

Bernard Meland, sebagaimana yang dikutip Clemens Sedmak, secara tidak langsung mengatakan bahwa budaya merupakan cara bagaimana manusia hidup, dengan melibatkan daya imajinasi dan ide, dan yang mengarahkan manusia untuk menghidupi atau mengekspresikan ide tersebut ke dalam suatu karya. ${ }^{7}$ Ini menunjukkan bahwa budaya merupakan aspek yang luas, dan didasarkan pada keyakinan atau norma yang diyakini bersama dalam menjalankan kehidupan. Budaya juga terkait dengan proses pem- belajaran seseorang yang kemudian diteruskan secara turun temurun, dan merupakan suatu kebiasaan hidup yang dilakukan secara komunal, di mana komunalitas tersebut berada dalam batasan geografis, sosial, dan juga historis. ${ }^{8}$ Oleh sebab itu, dapat dikatakan bahwa budaya memiliki lokalitas sosial tertentu, atau yang dapat disebut sebagai budaya lokal. Inilah yang kemudian membuat budaya menjadi beragam sesuai dengan lokalitasnya masingmasing.

Secara sederhana, budaya lokal didefinisikan sebagai, "Everything that we create and share as part of our lives in the place where we live or work".9 Terminasi budaya lokal juga secara umum dipakai untuk mengkarakterisasikan pengalaman keseharian masyarakat yang lebih spesifik. Lokalitas yang lebih bisa diidentifikasi, dan juga merupakan cerminan dari perasaan masyarakat pada umumnya terhadap suatu kelayakan, kenyamanan, dan kebenaran - di mana hal-hal ini berpengaruh terhadap pilihan dan perubahan selera personal. ${ }^{10}$ Budaya juga sebagai keseluruhan cara hidup, yang mencakup nilai (gagasan abstrak), norma (prinsip atau aturan terbatas), dan benda-benda material atau simbolis. ${ }^{11}$

Berdasarkan penjelasan budaya di atas, terlihat bahwa budaya lokal menjadi konteks keseharian hidup manusia secara

7. Clemens Sedmak, Doing Local Theology: A Guide for Artisans of a New Humanity (Maryknoll, NY: Orbis Books, 2005), 73.

8. Sedmak, Doing Local Theology, 74.

9. Wisconsin Teachers of Local Culture, (diakses 24 Juni 2015). Budaya lokal juga mengakui atau mencakup kompetensi yang dimiliki oleh masyarakat dalam menghidupi kehidupannya.

10. Ensiklopedia Britannica, Local Culture Society, (diakses 9 Juli 2015).

11. Chris Barker, Cultural Studies: Teori dan Praktik, terj. Nurhadi (Bantul: Kreasi Wacana, 2009), 39-40. Konsep William adalah konsep antropologis, karena berpusat pada makna sehari-hari. 
individu dan komunitas, yang di dalamnya terjadi pembentukan pola pikir, terlatih untuk berbahasa, serta memiliki sistem atau nilai-nilai tertentu. Budaya lokal juga mencakup apapun yang dikerjakan di dalam ruang tertentu, yaitu letak geografis secara luas dan juga lokalitas yang lebih spesifik, yang di dalamnya suatu komunitas hidup dan berinteraksi. Interaksi tersebut dijalankan dengan tiga aspek yaitu, nilai atau norma yang diyakini bersama, perilaku, dan hasil karya. Tiga as pek budaya lokal inilah yang menjadi bagian dari keutuhan ibadah itu sendiri.

Pertama, aspek nilai. Dalam ibadah komunal, jemaat membawa nilai atau konsep yang sama-sama dipercaya dalam sosialitas. Hal ini juga terkait dengan tujuan mereka berkumpul, siapa yang disembah, identitas diri di hadapan Tuhan, dan di tengah komunitas, juga nilai-nilai yang terkait dengan kehidupan sosial jemaat. Nilai kehidupan sosial ini sendiri terkait dengan norma atau aturan yang dipegang dalam lingkup sosial, seperti kesopanan (cara berpakaian, tingkah laku), adat istiadat, dan lainnya. Nilai-nilai inilah yang membentuk konsep dan pola pikir, menentukan perasaan, interaksi, atau relasi dalam kelokalan hidup sehari-hari, dan inilah yang kemudian terbawa ke dalam ibadah.

Dengan demikian, nilai menjadi bagian dari keutuhan individu dan komunitas yang datang beribadah, dan nilai yang dibawa itu berelasi dengan Allah dan je- maat lainnya. Nilai itu juga yang berdialog dan berpartisipasi dengan nilai dari Cerita Allah yang diritualisasikan di dalam ibadah komunal melalui elemen-elemen liturgi, dan dalam cara bagaimana jemaat itu sendiri dapat menerima dan memahami nilai tersebut. Dialog ini melatih, membentuk, dan membaharui nilai dalam cerita manusia. Nilai buruk yang bisa saja selama ini terbentuk dalam keseharian, yang sering kali dengannya identifikasi diri terjadi (tidak dikasihi, tidak berharga, dan tidak bisa berbuat apa-apa), kemudian diperbaharui oleh nilai Cerita Allah yang mengatakan bahwa mereka dikasihi Allah apa adanya, dan kasih itu tidak terkondisikan dengan apapun juga. Nilai dari Cerita Allah yang diritualisasikan di dalam ibadah (melalui lagu, khotbah, dan lainnya), juga membaharui nilai jemaat yang mungkin selama ini hanya diyakini berdasarkan kesepakatan sosial, bukan kebenaran Allah.

Kedua, aspek perilaku. Dalam komunitas, akan terlihat suatu perilaku yang sama dalam menyikapi satu hal tertentu, dan inilah yang dinamakan perilaku dari hasil kebudayaan. ${ }^{12}$ Perilaku adalah wujud dari suatu nilai, sebab keduanya saling terhubung satu sama lain. Dalam kebudayaan itu sendiri, terdapat istilah yang dibawa oleh Paul Hiebert, yaitu Folk System (deskripsi orang mengenai budaya mereka sendiri, dan mengenai bagaimana mereka menginterpretasikan budaya tersebut), dan Real Culture (pola perilaku

12. Carol R. Ember dan Melvin Ember, "Konsep Kebudayaan”, dalam Pokok-Pokok Antropologi Budaya, ed. T. O. Ihromi (Jakarta: Yayasan Obor Indonesia, 2013), 14.

\section{$28 \underset{\text { ministry }}{\text { Youlf November } 2015}$}




\section{Di dalam ibadah komunal, perilaku yang dilakukan jemaat didasarkan pada nilai kebenaran dari Cerita Allah, dan ini diajarkan melalui ritual gerakan, bahasa verbal, dan lainnya, yang di dalamnya jemaat ikut berpartisipasi.}

yang terjadi secara aktual). ${ }^{13}$ Menurut penelitian Hiebert, sering kali terjadi fenomena ketidaksesuaian antara sistem dengan apa yang nyata terjadi, dan juga terjadi fenomena lain, di mana suatu perilaku bisa saja terwujud tanpa ada konsep atau nilai yang mendasarinya.

Dalam ibadah komunal, jemaat datang dengan nilai dan perilaku yang melekat dalam sosialitas mereka, sehingga perilaku juga menjadi bagian dari keutuhan individu maupun komunitas yang saling berelasi, yang juga dengannya jemaat berpartisipasi melalui bahasa tubuh tertentu, dan yang kemudian mengalami pem baharuan karena berinteraksi aktif dengan Cerita Allah. Jemaat bisa saja datang dengan nilai ideal atau sistem lokal yang selama ini tidak sesuai dengan kelakukan sebenarnya, atau bisa juga jemaat memiliki tindakan rutin yang dilakukan tanpa makna yang mendasarinya. Sesungguhnya, Cerita Allah dalam ibadah membaha- rui hal-hal ini, agar tidak terdapat jurang antara nilai atau sistem lokal dengan tindakan yang terwujud.

Perilaku juga terkait dengan bahasa tubuh (seperti ekspresi kegembiraan dengan sorak sorai, ber tepuk tangan, atau dapat juga diwujudkan secara lebih tenang, tanpa gerakan tubuh, dan lainnya), sesuai dengan kebiasaan yang dilakukan dalam lokalitas masing-masing. Di dalam ibadah komunal, perilaku yang dilakukan jemaat didasarkan pada nilai kebenaran dari Cerita Allah, dan ini diajarkan melalui ritual gerakan, bahasa verbal, dan lainnya, yang di dalam nya jemaat ikut ber partisipasi. Sebagai contoh, nilai persaudaraan yang diwujudkan dalam ritual ibadah melalui bahasa "kita bersaudara dalam Tuhan" atau kalimat lainnya, yang disertai dengan tindakan bersalaman, bergandengan tangan (sesuai dengan kebiasaan lokalitas masing-masing). Membuat tindakantindakan tersebut bukan lagi sekadar tindakan menjunjung solidaritas sosial, atau tindakan tanpa makna. Akan tetapi, didasarkan pada nilai Cerita Allah yang disampaikan melalui ibadah, yang kemudian diimplementasikan dalam keseharian.

Ketiga, aspek hasil karya. Hiebert mengatakan, "pemikiran (konsep atau nilai) dan perilaku manusia sering kali memimpin kepada produksi benda-benda material atau alat-alat." ${ }^{14}$ Hasil karya adalah wujud dari integrasi nilai dan perilaku, yang disebut Hiebert sebagai Cultural Configuration (bentuk yang tersusun se-

13. Paul G. Hiebert, Cultural Anthropology (Grand Rapids: Baker, 1999), 47.

14. Hiebert, Cultural Anthropology, 29. 
cara budaya). ${ }^{15}$ Karya menjadi suatu media penyampaian makna dalam interaksi sosial. Dengan demikian, karya memiliki kekuatan untuk mengidentifikasi lokalitas tertentu, begitu juga dengan nilai dan perilaku yang terkandung di dalamnya.

Jemaat datang beribadah dengan kebiasaan untuk berinteraksi dalam lokalitas mereka melalui karya tertentu, seperti media teknologi, alat musik, nyanyian, simbol-simbol, dan lainnya. Kehidupan sosial jemaat dekat dengan karya, sebagai media penyampaian nilai dan perilaku yang terkandung di dalamya. Sehingga karya juga menjadi bagian dari keutuhan individu maupun komunitas yang saling berelasi, berpartisipasi, dan juga yang kemudian akan dibaharui. Dalam ibadah komunal, terdapat hasil karya seperti nyanyian, musik, tarian, simbol, alat musik, dan visualisasi, yang diimplementasikan untuk menyampaikan, melatih, dan membentuk nilai serta perilaku yang didasarkan pada kebenaran Cerita Allah. Sebagai contoh adalah nyanyian dengan jenis musik dan bahasa lokal tertentu, yang melaluinya tersampaikan Cerita Allah mengenai anugerah-Nya, dan yang kemudian diwujudkan melalui bahasa tubuh lokal yang bersangkutan, seperti bertepuk tangan, menari, bersalaman, dan lain sebagainya.

Dari penjelasan di atas, terlihat bahwa kehidupan jemaat terikat dan terbentuk dalam tiga aspek budaya lokal, sehingga budaya lokal itu sendiri menjadi bagian yang kuat dalam keutuhan suatu ibadah komunal. Ini terjadi sebab budaya lokal terkait erat dengan keutuhan kehidupan jemaat, baik sebagai individu maupun komunitas, yang dengan budaya lokal itu sendiri jemaat berpartisipasi. Ketika jemaat mengalami suatu pembaharuan, maka budaya lokal itu jugalah yang akan dibaharui. Dengan demikian, dalam mewujudkan ibadah komunal kau m muda yang utuh, maka budaya lokal kaum muda menjadi bagian yang penting untuk dipertimbangkan.

\section{Budaya Lokal dalam Ibadah Komunal Kaum Muda}

Perjalanan kehidupan kaum muda merupakan perjalanan yang kompleks, dengan berbagai kerinduan dan tantangan yang mereka hadapi, baik itu dalam pencarian jati diri, relasi yang murni, penghargaan yang tulus, bahkan pengakuan akan keterlibatan Allah di dalam keseharian mereka. Pencarian itu berlangsung sampai ke dalam ibadah komunal. Jika mereka tidak menemukan itu semua di dalam ibadah, maka mudah bagi mereka untuk berpaling, dan mencari di tempat lain, sebab mereka mempunyai banyak energi untuk melakukannya. Dengan demikian, tidak jarang kita mendengar ada banyak kaum muda yang berpindah gereja karena alasan ibadah yang terlalu kaku, atau mereka tidak mau terlibat dalam pelayanan ibadah, cepat bosan ketika beribadah, bahkan bisa saja tidak beribadah sama sekali. Atau, justru rajin beribadah namun kesehariannya tetap

15. Hiebert, Cultural Anthropology, 30. 
sama, tetap terikat dengan berbagai pergumulan dosa. Jika demikian yang terjadi, maka ini menjadi peringatan besar bagi ibadah komunal kaum muda yang sudah berlangsung selama ini.

Jika bukan ibadah komunal yang memengaruhi hidup mereka, maka tidak akan ada yang bisa membendung pengaruh seperti apa yang membentuk nilai hidup mereka di luar sana; perilaku apa yang mereka lakukan dalam keseharian untuk mewujudkan nilai itu; dan karya jenis apa yang mereka hasilkan. Dengan demikian, transformasi yang utuh itu sendiri sulit untuk dicapai, sebab ibadah tidak menyentuh keutuhan dari hidup mereka, termasuk budaya lokal mereka sendiri yang dengannya mereka menjalankan keseharian hidup. Oleh sebab itu, dalam merancang ibadah kaum muda yang utuh, maka memerlukan beberapa prinsip yang mempertimbangkan budaya lokal kaum muda. Akan tetapi, bagaimana budaya lokal itu sendiri dipertimbangkan dalam ibadah komunal kaum muda? Prinsip yang seperti apa yang perlu untuk dipegang, terkait dengan mempertimbangkan budaya lokal itu sendiri?

Pertama, mempertimbangkan budaya lokal kaum muda sebagai konteks terdekat ibadah. Prinsip ini mengupayakan nilai, perilaku, dan karya terdekat kaum muda, agar ibadah komunal mereka tidak menjadi suatu aktivitas spiritual yang jauh, melainkan menjadi bagian terdekat dalam kehidupan nyata mereka. Prinsip ini diupayakan dengan memahami situasi dan kondisi sebenarnya yang sedang dialami oleh kaum muda. Begitu juga dengan memahami ritual apa yang sering mereka lakukan dalam rutinitas keseharian (seperti makan bersama keluarga, teman, atau mungkin bolos bersama), dan cerita apa yang sedang mereka bagi melalui ritual-ritual tersebut. Dengan demikian, ibadah akan mengenal nilai, perilaku, dan karya terdekat kaum muda, yang kemudian diwujudkan di dalam doa, nyanyian, lagu, khotbah, dan sebagainya.

Sebagai contoh adalah pengakuan dosa. Penatalayan perlu memimpin doa yang jujur dan otentik, sesuai dengan keberadaan kaum muda yang sebenarnya, yang bukan hanya sekadar bahasa keagamaan yang terlampau umum. ${ }^{16}$ Kalimat yang dikatakan adalah seperti "Tuhan, ampuni kami yang masih saja malas belajar, malas berdoa, dan hidup egois. Am-

16. Bahasa keagamaan yang dimaksud penulis adalah terkait dengan bahasa baku yang secara umum diucapkan tiap minggu, seperti "Kita bersyukurkarena Tuhan masih memberikan kita kesempatan," atau "Mari kita memohon kepada Allah untuk mengampuni dosa kita, yang sering kita lakukan. Kiranya Allah mau mengampuni semua dosa kita." Sesungguhnya, ini merupakan bahasa rohani yang umum, dan sering kali membuat pemimpin ibadah tidak secara kritis dan kreatif dalam memikirkan apa yang dapat disampaikan melalui doa, sapaan, atau nyanyian, yang secara nyata sedang dialami oleh jemaat. Sering kali apa yang dilakukan di dalam ibadah adalah hanya sekadar pengulangan bahasa keagamaan di setiap minggunya, dan berharap agar tercipta suatu kesadaran dan terjadi dialogyang dinamis dengan jemaat, sedangkan jemaat sendiri sudah tau apa yang akan dikatakan oleh pemimpin ibadah. Is tilah bahasa keagamaan ini sendiri penulis ambil dari ide seorang tokoh, yang teori dan pemikirannya cukup berpengaruh dalam dunia pendidikan agama Kristen bagi anak-anak. Tokoh tersebut adalah Horace Bushnell, sebagai penulis dari buku Christian Nurture. Beliau mengkritik bahasa keagamaan atau bahasa figuratif yang dirumuskan para teolog untuk menjadi suatu bahasa atau rumusan yang baku dalam kekristenan. Sebagai contoh adalah rumusan teologi-teologi Kristen, yang menurutnya, bahasa keagamaan tersebut sesungguhnya belum secara utuh menggambarkan kenyataan rohani yang sebenarnya. Lihat Donald A. Crosby, Horace Bushnell's

Theory of Language: In the Context of Other Nineteenth-Century (Paris: Mounton \& Co. B.V., publishers, 1975. Atau William A. Johnson, Nature and the Supernatural in the Theology of Horace Bushnell (Lund: Berlingska Boktryckeriet, 1963). 
puni kami yang masih suka menggosipkan teman, dan menghasut teman sendiri." Atau juga "ampuni kami yang masih suka bolos," dan lain sebagainya. Dengan demikian, pengakuan dosa menjadi suatu pengakuan yang otentik dan dekat dengan budaya lokal kaum muda, sehingga mereka menjadi terbiasa untuk menghadap Tuhan secara otentik, bukan hanya di ibadah, melainkan juga dalam keseharian. Ini semua untuk mengupayakan bagaimana kedekatan itu membuat mereka bersedia menyediakan keberadaan diri yang utuh untuk berpartisipasi lebih dalam.

Kedua, mempertimbangkan budaya lokal kaum muda sebagai bagian dari keutuhan ibadah. Pada penjelasan sebelumnya telah ditekankan bahwa rupanya budaya lokal merupakan bagian dari keutuhan individu dan komunitas, yang dengannya, individu dan komunitas tersebut berelasi dan berinteraksi secara utuh. Dengan demikian, budaya lokal itu sendiri perlu dipertimbangkan sebagai bagian dari keutuhan suatu ibadah. Sebab dengan budaya lokal itu, individu dan komunitas datang beribadah, dan berpartisipasi di dalam ibadah. Mempertimbangkan prinsip ini dapat menyatukan ibadah dan kaum muda itu sendiri.

Prinsip ini terkait dengan bagaimana agar di dalam ibadah komunal, kaum muda melibatkan keutuhan diri mereka, baik itu secara individu maupun komunitas. Ini juga mengupayakan bagaimana kaum muda dapat menyadari keutuhan mereka sebagai makhluk kultural sekaligus spiritual, bahwa "serelevan" apapun budaya mereka, terdapat hal spiritual yang tidak

\section{Prinsip ini diupayakan agar} kaum muda dapat mengalami ibadah dengan keutuhan dirinya, sebagai individu dan komunitas seutuhnya, yang bukan hanya di dalam ibadah komunal saja, namun juga di dalam rumah, sekolah, dan lainnya. Demikian juga, prinsip ini dapat membangkitkan relasi dalam komunal, yang juga menjadi bagian dari keutuhan hidup dalam sosialitas mereka.

dapat digantikan oleh budaya manapun. Prinsip ini juga memberikan kesadaran bahwa "selokal-lokalnya" ibadah mereka, mereka juga adalah bagian dari keutuhan yang global, yaitu satu kesatuan tubuh Kristus, yang mencakup seluruh komunitas Kristen yang ada di dunia. Oleh sebab itu, kita juga perlu memperhatikan halhal global yang sama-sama diyakini oleh komunitas Kristen di manapun mereka berada, seperti pengakuan iman, baptisan, perjamuan kudus, dan lain sebagainya. Prinsip ini diupayakan agar kaum muda dapat mengalami ibadah dengan keutuhan dirinya, sebagai individu dan komunitas seutuhnya, yang bukan hanya di dalam ibadah komunal saja, namun juga di dalam rumah, sekolah, dan lainnya. Demikian juga, prinsip ini dapat membangkitkan relasi dalam komunal, yang juga menjadi bagian dari keutuhan hidup dalam sosiali- 
tas mereka.

Sebagai contoh, penggunaan bahasa asing pada nyanyian. Jika bahasa inggris bukan merupakan budaya lokal kaum muda tertentu, maka lagu tersebut hanya sekadar sebuah nyanyian tanpa pemaknaan yang mendalam. Mereka sedang tidak secara utuh menyanyikan lagu tersebut, karena hati, mulut, pikiran, dan perasaan tidak berdialog secara utuh dan dinamis. Dengan demikian, lagu tersebut tidak hanya tidak dipahami secara mendalam, melainkan juga tidak hidup di dalam keseharian mereka. Begitu juga dengan bahasa tubuh yang dipakai di dalam ibadah. Jika ibadah memakai nyanyian yang bahasa tubuhnya bukan merupakan budaya lokal kaum muda tertentu, seperti berdiri kaku selama bernyanyi, dan lainnya, maka hal ini akan membuat mereka tidak secara utuh dalam memberikan partisipasinya. Kalaupun dilakukan, sesungguh nya itupun hanya sekadar tindakan "ikut-ikutan", tanpa suatu penghayatan dan pemaknaan yang utuh.

Prinsip ini juga diupayakan agar tidak tercipta jurang antara nilai, perilaku keseharian, dan hasil karya kaum muda. Sebagai contoh adalah nilai sosial kaum muda yang menjunjung kerja sama, namun pada kenyataannya, mereka tetap mengekspresikan hidup yang individualistik. Ketika ibadah memahami keadaan ini, maka doa, khotbah, pengakuan dosa, lagu, akan secara jujur berbicara terkait dengan keberadaan ini. Dengan demikian, nilai tersebut akan diperjelas lagi di dalam ibadah, bahwa kerjasama bukan hanya sekadar nilai budaya, melainkan sebagai respons tubuh Kristus terhadap kesela- matan dari Allah. Prinsip ini juga mengintrospeksi kembali nilai, perilaku, dan karya, yang selama ini bukan hanya tidak sesuai dengan nilai budaya, melainkan juga dengan kebenaran Allah. Dengan demikian, nilai, perilaku, dan karya, yang diajarkan di dalam ibadah menjadi utuh dengan apa yang akan dilakukan di dalam keseharian, dan budaya lokal kaum muda itu sendiri mengalami suatu transformasi di dalam pengalaman ibadah tersebut.

Ketiga, prinsip dengan mempertimbangkan motif transformatif dalam budaya lokal kaum muda. Prinsip ini tidak hanya sekadar mengupayakan agar ibadah menjadi dekat, dan utuh dengan kaum muda, melainkan semua yang dilakukan dalam ibadah (seperti penyesuaian dengan budaya lokal kaum muda, dan lainnya), perlu memikirkan bagaimana agar budaya lokal kaum muda sendiri dapat dibaharui. Pemilihan lagu, penggunaan bahasa tubuh, atau visualisasi melalui simbol atau karya yang dipilih di dalam ibadah. Perlu didasari pada prinsip bahwa apakah semuanya itu membangun nilainilai kekristenan yang mentransformasi, atau hanya sekadar "seru-seruan" yang menyenangkan mata, perasaan, dan hati kaum muda. Sehingga, ibadah kaum muda perlu diuji kembali apakah terdapat tindakan yang dilakukan tanpa makna, atau sebagai ritual tanpa cerita di dalamnya, atau juga hanya sebagai perayaan budaya tanpa tujuan. Ibadah komunal kaum muda perlu memberikan pemaknaan-pemaknaan terhadap apa yang dilakukan di dalam ibadah, seperti duduk, berdiri, berlutut, bertepuk tangan, melompat-lompat, dan sebagainya. 
Sebagai contoh adalah tindakan bersalaman, mengucapkan "apa kabar" dan memberikan senyum kepada jemaat lain. Ini dilakukan bukan hanya untuk mencairkan suasana, melainkan membuat mereka memaknai hal tersebut sebagai tindakan hospitalitas yang sudah diajarkan Yesus melalui inkarnasi diri-Nya. Oleh sebab itu, mereka memahami untuk apa mereka bersalaman, dan dengan demikian terjadi suatu pembaruan melalui pengalaman ibadah tersebut. Prinsip in i tidak hanya sekadar mendekatkan ibadah dengan budaya lokal sebagai konteks terdekat. Begitu juga tidak hanya sekadar agar dengan kedekatan tersebut kaum muda dapat berpartisipasi secara utuh. Melainkan juga, bagaimana agar tercapai suatu transformasi yang utuh di dalam pengalaman ibadah yang utuh. Semua in i tentu dengan tidak mengesampingkan totalitas intervensi Allah dalam mewujudkannya.

Ketiga prinsip di atas memberikan kita sebuah hasrat untuk mempertanyakan lagi ibadah komunal kaum muda yang sudah berjalan sejauh ini. Dengan prinsip apa selama ini ibadah komunal kaum muda berjalan? Apa yang yang diharapkan terjadi saat Cerita Allah bertemu dengan cerita kaum muda di dalam ibadah komunal? Apakah ibadah komunal kaum muda selama ini telah menjadi ibadah yang dekat dengan hidup dan hasrat dari kaum muda itu sendiri? Apakah mencakup keutuhan hidup mereka secara personal dan komunal, sebagaimana yang dikehendaki Allah, sampai keutuhan hidup itu sendiri mengalami pembaharuan oleh Allah? Topik kita kali ini memberikan kita sebuah kesadaran bahwa budaya lokal kaum muda perlu untuk dipertimbangkan dalam mengupayakan pertanyaanpertanyaan tersebut dapat terjawab dalam ibadah komunal kaum muda. Kiranya Tuhan menolong kita. Amin.

\section{Youlfh | November 2015}




\section{Daftar Pustaka}

Anderson, Herbert dan Edward Foley. Mighty Stories, Dangerous Rituals: Weaving Together the Human and the Divine. San Francisco, California: Jossey-Bass, 1998.

Barker, Chris. Cultural Studies: Teori dan Praktik. Terj. Nurhadi. Bantul: Kreasi Wacana, 2009.

Crosby, Donald A. Horace Bushnell's Theory of Language: In the Context of Other Nineteenth-Century. Paris: Mounton \& Co. B.V., publishers, 1975.

Ember, Carol R. dan Melvin Ember. "Konsep Kebudayaan.” Dalam Pokok-pokok Antropologi Budaya. Ed. T.O. Ihromi. Jakarta: Yayasan Obor Indonesia, 2013.

Hiebert, Paul G. Cultural Anthropology. Grand Rapids: Baker, 1999.

Johnson, William A. Nature and the Supernatural in the Theology of Horace Bushnell. Lund: Berlingska Boktryckeriet, 1963.

King, Robert R. "Under the Mango Tree: Worship, Song, and Spiritual Transformation in Africa." Dalam Worship that Changes Lives: Multidisciplinary and Congregational Perspective on Spiritual Transformation. Ed. Alexis D. Abernethy. Grand Rapids: Baker Academic, 2008.

Schmit, Clayton J. "Worship as a Locus for Transformation." Dalam Worship that Changes Lives: Multidisciplinary and Congregational Perspective on Spiritual Transformation. Ed. Alexis D. Abernethy. Grand Rapids: Baker Academic, 2008.

Sedmak, Clemens. Doing Local Theology: A Guide for Artisans of a New Humanity. Maryknoll, NY: Orbis Books, 2005.

Segler, Franklin M. dan Randall Bradley. Christian Worship: Its Theology and Practices. Nashville: B\&H, 2006.

Ensiklopedia Britannica, Local Culture Society, http://www.britannica.com/topic/localculture (diakses 9 Juli 2015).

Wisconsin Teachers of Local Culture, http://csumc.wisc.edu/wtlc/?q=exploring (diakses 24 Juni 2015). 